\title{
Game Theory Approach on the Abuse-of-Power Crime
}

\author{
Wuwei Zhang ${ }^{1}$ \\ ${ }^{1}$ Chuxiong Normal University, \\ Chuxiong, Yunnan, China \\ Mingwu Zhou ${ }^{1}$ \\ ${ }^{1}$ Chuxiong Normal University, \\ Chuxiong, Yunnan, China
}

\author{
Hongli Peng ${ }^{1}$ \\ ${ }^{1}$ Chuxiong Normal University, \\ Chuxiong, Yunnan, China \\ Aimei Wang ${ }^{1}$ \\ ${ }^{1}$ Chuxiong Normal University, \\ Chuxiong, Yunnan, China
}

\begin{abstract}
This paper constructs the game model describing the abuseof-power crime with players, strategy sets and payoff function. Based on this model, we analyse the law that guide the abuse-of-power crime and find out the reason why it prevails, including the cyclical patern of decision making between principal and agent. Through the analysis of the function of the abuse-of-power crime, the corresponding conclusion is drawn.
\end{abstract}

Keywords: Game Abuse-of-Power Crime

\section{Introduction}

According to the data from the Commission for Discipline Inspecion of the Central Committee of the CPC, among all the investigated officials in the year 2013, the detailed information of 123 of them is revealed.31 of them are convicted. With regard to the level of their position, 27 of them are provincial or ministerial level officials, taking up $21.1 \%$ of the total revealed officials. 70 of them are department or bureau level officials, taking up 56.9\% of the total.26 of them are county level officials, taking up $21.1 \%$. The above revealed number means that for each month there are two provincial or ministerial level officials and 6 department or bureau level officials being investigated. Mo Jihong, vice chief of the law institute of Chinese Academy of Social Science, has always focused on the anti-corruption movement in China. He has estimated roughly the number of high-level officials from 1987 to 2012 and the number of high-level officials convicted in this period is 145 ,including 3 member of the CPC Central Committee Political Bureauz. But in the year 2013 alone, there were 31 people convicted, which amounts to 5.25 times of the previous 25 years' average. However, this trend gets stronger, from January to june,2014,2 Deputy State level officials were convicted. Jihong Mo said, when he is interviewed by the China Economics Weekly, that this means that both the efficiency and effecacy of anti- corruption movement have improved, Catching high-level officials was more seriously stressed. Besides stressing the anti-corruption law enforcement, the government has also curbed three public consumptions, i.e.overseas trips, vehicle purchasing and maintenance and official receptions. This has shown central government's determination and action in curbing the practices of corruption and power abuse. Under these actions, the three public consumptions of central government has reduced $35 \%$, and that of local government has reduced 26\%.Qishan Wang, the vice prime minister who is in charge of anti-corruption movement in China, has remarked: the soil for the seed of corruption to grow still lie there, so we still face a very severe situation of anti-corruption enforcement.

In the study of criminal law, the so called abuse-ofpower crime, refers to the intentional or unintentional abuse of power that violates the law by people of certain post working in the government or public utility. there are various forms this crime, namely, offering or accepting bribery, corruption, appropriation, embezzlement, dereliction. The Prevention of such crimes has becomes a highly concerned topic of various governments and is considered as of vital importance to build the rule of law.

In the following session, we use game theory to model abuse-of-power crime and try to find out the rule of abuseof-power crime involvement.

\section{Model for the abuse-of-power crime}

\subsection{Players in the game of abuse-of-power crime}

There are three players in the game, namely principal, agent and profit seeker, the agents refer to two groups of people: first, government officials, the powers of whom come from the post, and is strictly authorized and regulated by laws. One can either exercise beyond these regulations, or waive the power. Second, staffs in public utility, or those work in public service institutions. Their right is also auhorisized by state laws or other power principal. Third, 
managerial in enterprises, and their power is authorized by shareholders. Our investigation reveals that abuse-of-power crime exists among these agents.

We take principal, agent and rent-seekers as rational individuals in economics. Every agent acts to maximize their payoffs. Meanwhile, we do not deny the altruistic behaviors of these rational individuals. The altruistic behavior in this paper refers to the actions out of the incentive to pursue multi-purpose benefit, or so called long term benefit, as opposed to short term benefit. We adopts the rational agent assumption as a abstract description of various incentives of all players.

\subsection{Constraint of players}

The truth of abuse-of-power crime is abusing the power to seek rents. The rent seekers have money, the power agent has power, rent-seeking activities thus occurs between corporate, the rent seeker, and the government or public utility staff, the power agent. The truth is, government interference would distort market clearing and adjustment, and lead to rent dissipation, but in this process new rent is produced because of resource shortage. In this way, the more interference, the higher the economic rent; the bigger the rent seeking incentive, the more severe the corruption behavior. Rent seeking activities from the agent is unavoidable because of the abundance of rent, and various with the value of rent from the market. The principal thus decide his optimal strategy according to the degree of power abuse among agents. This is the the environment of principals and agents.

It has to meet two constraint before a problem becomes a principla-agent problem: (i)both the principal and the agent must be mutually independent profit seeking individuals, and they acts to maximize their own profit;(ii)the interest of principals and agents do not concord, and the action of agent would significantly affect the interest of the principal;(iii)the performance of agent is not solely determined by its own activities, but also the nature(random factors of the circumstances). It's difficult for the principal to observe its activities, so the the activities of agent cannot be judged by performance alone. In a principal-agent relation, the principal cannot get hold of all information because of constraint, so in information economics, the party who grabs private information is called agent, while the party that do not is called principal. The asymmetry of information makes principal unable to supervise the actions of agent and it is hardly known that whether the agent abuses power or not. Thus the difference of purposes between the principal and agent provide the agent with the incentive to seek profit by impairing the interest of the principal using his information advantage, in circumstances where the incentive mechanism, responsibility mechanism, and supervision mechanism is incomplete.

\subsection{Strategies of players in the game}

Players choose strategies to optimize their payoffs. Gary Becker(1968) is the first to analyse criminal behavior with economics thinking, and take crime as a profit seeking activities. So the decision of conducting criminal behavior is the solution to the profit optimization with certain constraint. In this paper, the strategy of the principal is: $\{1,0\}$, in which $1=$ prosecute or strictly investigate and prosecute, $0=$ not prosecute or not seriously investigate. The strategy of the agent is defined as: $\{1,0\}$, in which $1=$ exercise abuse-of-power crime, $0=$ do not exercise abuseof-power crime. The strategy of profit seekers is defined as: $\{1.0\}$, in which $1=$ resort to bribe and $0=$ not resort to bribe.

In this game, the agent would exercise abuse-of-power crime out of his own profit maximization incentive, the rent seeker would lure the agent to abuse his power in order to optimize his own benefit. The principal would take precautions against crimes or take means to control the abuse-of-power crimes on the purpose of optimize his own profit. The most important means to prevent and control crimes is to investigate and prosecute, i.e. exercise severe punishment on criminal agent. It requires the principal to pay certain cost to investigate and prosecute the agent, and this cost-benefit consideration determines the severity of investigation and prosecution, which denote the degree of punishment in Becker(1968)'s analysis, by the principal.

\subsection{Payoff function of players}

The payoff function denotes the payoffs of certain strategy chosen by players. Both the abuse-of-power crimes and the control of crimes are profit seeking activities, so there exists a market of crimes. The penalty on criminal agents are regulated by the law, namely death penalty, custody, career constraint and demotion. The cost of punishment can be measured by certain amount of currency, or directly measured by the amount of forfeit. We assume that in a market of crimes:

(i)If the principal authorize the agent to exercise a set of proprietary rights, for one factor in this set of rights $x \in X$, the value of $\mathrm{x}$ is $\mathrm{V}$.

(ii)If the agent exercise the abuse-of-power crime, the market value of $x$ would suffer from a loss of $\triangle V$, if the agent exercise the crimes of corruption, appropriation and embezzlement, his benefit is the market value loss $\triangle \mathrm{V}$ because the agent abuse his power to appropriate the interest of the principal. If the agent exercise the crime of taking bribery, the rent seeker would bribe the agent with an amount of $\mathrm{k} 。 \triangle \mathrm{V}$, so the rent seeker gets the remaining $(1-\mathrm{k} 。) \triangle \mathrm{V}$ of the total benefit of abusing the power.

(iii)The wage income of the agent is W. If the principal finds that the agent commits crime, the agent would lose all wage income, but the principal has to pay a cost of $\mathrm{C}$ to check and supervise the agent's behavior.

\subsection{The function of the amount of the abuse-of-power crime}

There is connection between the revenue of committing crimes, the probability of getting caught, and the severity of punishment after conviction, the connection can be described using a function

$$
O_{i}=O_{i}\left(g_{i}, p_{i}, \mathrm{f}_{i}, u_{i}\right)
$$


In Becker(1968)'s analysis, the income of commiting crime $\mathrm{g}_{\mathrm{i}}$ is not considered as a prime factor that influence the number of crimes. However, in terms of the abuse-ofpower crime, the increase of the revenue from commiting crimes would definitely lead to the rise the number of crimes. So we include this variable in the function.

\section{Analysis of the abuse-of-power game}

\subsection{Nash equilibrium}

We adopts the Nash equilibrium in analyzing this game.

\section{2. the game between rent seekers}

\section{(i)game between two rent seekers}

There are only two rent seekers in the market with similar capabilities(e.g. two competitive companies), for rent seekers $\left\{A_{1}, A_{2}\right\}, I=\{1,2\}$, the set of strategy is $S_{i}=$ $\{0,1\}$,in which 0 means not bribe, 1 means bribe, $i=1,2$, there are 4 strategy combinations $S_{1} \times S_{2}=$ $\{(0,0),(0,1),(1,0),(1,1)\}$,and the payoff function of the two rent seekers are $H_{i}\left(S_{1} \times S_{2}\right), i=1,2$, which are known to all as public information. But neither of the two players know the other's chosen strategy. The sum of the two players' payoff function is constant, which means their benefit is mutually contradictory and competitive, so this is a complete information static game. The rent seekers would always retrieve the most rent from the market to optimize his profit, so he pays the agent to get the right $\mathrm{x}$, which is the power authorized by the principal, with a price less than the value of $\triangle \mathrm{V}$. If both players do not bribe, the payoffs of both $A_{1}$ and $A_{2}$ are $\triangle V / 2$. If one player bribe and the other do not, then the player that bribes get a payoff of $(1-\mathrm{k} 。) \triangle \mathrm{V}$, the player that do not bribe gets payoff of 0 . The payoff matrix is as follows:

\begin{tabular}{|l|c|c|c|}
\hline \multicolumn{1}{|c|}{ players } & Strategy & $\begin{array}{c}\text { Payoff of } \mathrm{A}_{1} \\
\mathrm{H}_{\mathrm{i}}\left(\mathrm{S}_{1} \times \mathrm{S}_{2}\right)\end{array}$ & $\begin{array}{c}\text { Payoff of } \mathrm{A}_{2} \\
\mathrm{H}_{\mathrm{i}}\left(\mathrm{S}_{1} \times \mathrm{S}_{2}\right)\end{array}$ \\
\hline $\mathrm{A}_{1} \mathrm{~A}_{2}$ bribes & $(1,1)$ & $\left(1 / 2-\mathrm{k}_{\circ}\right) \Delta \mathrm{V}$ & $\left(1 / 2-\mathrm{k}_{\circ}\right) \Delta \mathrm{V}$ \\
\hline $\mathrm{A}_{1}$ bribes & $(1,0)$ & $\left(1-\mathrm{k}_{\circ}\right) \Delta \mathrm{V}$ & 0 \\
\hline $\mathrm{A}_{2}$ bribes & $(0,1)$ & 0 & $\left(1-\mathrm{k}_{\circ}\right) \Delta \mathrm{V}$ \\
\hline No one bribes & $(0,0)$ & $\Delta \mathrm{V} / 2$ & $\Delta \mathrm{V} / 2$ \\
\hline
\end{tabular}

According to our analysis, bribery brings payoffs back to the rent seeker, the nash equilibrium of this game is \{bribe, bribe $\}$. In equilibrium, no one would deviate from the equilibrium because deviation reduces the payoff. Although brib is the optimal strategy of both players, but the equilibrium payoff $\{(1 / 2-\mathrm{k} 。) \triangle \mathrm{V},(1 / 2-\mathrm{k} 。) \triangle$ $\mathrm{V}$ \} is not the best payoff they can attain. If both of them do not bribe, they would all get the payoff $\triangle \mathrm{V} / 2$, greater than the equilibrium payoff. So this is a very typical "prisoner dillema".

(ii)Game of three rent seekers

If there are 3 rent seekers on the market, the players are $\left\{\mathrm{A}_{1}, \mathrm{~A}_{2}, \mathrm{~A}_{3}\right\}$, the strategy set is $\mathrm{S}_{\mathrm{i}}=\{0,1\}$,in which 0 means not bribe, 1 means bribe, $\mathrm{i}=1,2$, there would be 8 strategy combinations $S_{1} \times S_{2} \times S_{3}=\{(0,0,0),(0,0,1)$,
$(0,1,0),(1,0,0),(0,1,1),(1,0,1\},(1,1,0)$,

$(1,1,1)\}$, the payoff function is $\mathrm{H}_{\mathrm{i}} \quad\left(\mathrm{S}_{1} \times \mathrm{S}_{2} \times\right.$ $\mathrm{S}_{3}$ ), $\mathrm{i}=1,2,3$. The payoff matrix is as follows:

\begin{tabular}{|l|c|c|c|c|}
\hline \multicolumn{7}{|c|}{ Tab2. Game of 3 rent seekers } \\
\hline All bribe & $(1,1,1)$ & $\begin{array}{l}\text { Payoff of } \mathrm{A}_{1} \\
\mathrm{H}_{1}\left(\mathrm{~S}_{1} \times \mathrm{S}_{2} \times \mathrm{S}_{3}\right)\end{array}$ & $\begin{array}{l}\text { Payoff of } \mathrm{A}_{2} \\
\mathrm{H}_{2}\left(\mathrm{~S}_{1} \times \mathrm{S}_{2} \times \mathrm{S}_{3}\right)\end{array}$ & $\begin{array}{l}\text { Payoff of } \mathrm{A}_{3} \\
\mathrm{H}_{3}\left(\mathrm{~S}_{1} \times \mathrm{S}_{2} \times \mathrm{S}_{3}\right)\end{array}$ \\
\hline $\begin{array}{l}2 \text { of them } \\
\text { bribe }\end{array}$ & $(1,1,0)$ & $\left(1 / 2-\mathrm{k}_{\circ}\right) \Delta \mathrm{V}$ & $\left(1 / 3-\mathrm{k}_{\circ}\right) \Delta \mathrm{V}$ & $\left(1 / 3-\mathrm{k}_{\circ}\right) \Delta \mathrm{V}$ \\
\hline $\begin{array}{l}2 \text { of them } \\
\text { bribe }\end{array}$ & $(1,0,1)$ & $\left(1 / 2-\mathrm{k}_{\circ}\right) \Delta \mathrm{V}$ & 0 & 0 \\
\hline $\begin{array}{l}2 \text { of them } \\
\text { bribe }\end{array}$ & $(0,1,1)$ & 0 & $\left(1 / 2-\mathrm{k}_{\circ}\right) \Delta \mathrm{V}$ & $\left(1 / 2-\mathrm{k}_{\circ}\right) \Delta \mathrm{V}$ \\
\hline 1 bribes & $(1,0,0)$ & $\left(1-\mathrm{k}_{\circ}\right) \Delta \mathrm{V}$ & 0 & 0 \\
\hline 1 bribes & $(0,1,0)$ & 0 & $\left(1-\mathrm{k}_{\circ}\right) \Delta \mathrm{V}$ & 0 \\
\hline 1 bribes & $(0,0,1)$ & 0 & 0 & $\left(1-\mathrm{k}_{\circ}\right) \Delta \mathrm{V}$ \\
\hline 0 bribes & $(0,0,0)$ & $\Delta \mathrm{V} / 3$ & $\Delta \mathrm{V} / 3$ & $\triangle \mathrm{V} / 3$ \\
\hline
\end{tabular}

According to our analysis, bribery brings payoffs back to the rent seeker, the nash equilibrium of this game is $\{$ bribe, bribe, bribe $\}$. In equilibrium, no one would deviate from the equilibrium because deviation reduces the payoff.

\section{(iii)the game of rent seekers}

If there are $\mathrm{n}$ rent seekers on the market, i.e. $\left\{A_{1}, A_{2}, \ldots \ldots, A_{n}\right\}$, the strategy set is $S_{i}=\{0,1\}$,in which 0 means not bribe, 1 means bribe, $i=1,2$, there would be $2^{\text {n }}$ strategy combinations: $\mathrm{S}_{1} \times \mathrm{S}_{2} \times \ldots \ldots \times \mathrm{S}_{\mathrm{n}}=\{(0,0, \ldots, 0)$, $(0,0, \ldots, 1), \ldots, \quad(0,1, \ldots, 0),(1,0, \ldots, 0)$, $(0, \ldots, 1,1) \quad, \ldots,(1,0, \ldots, 1 \quad\} \quad, \ldots,(1,1, \ldots, 0), \ldots$, $(1,1, \ldots, 1)\}$,the payoff function is $H_{i}\left(S_{1} \times S_{2} \times \ldots \ldots \times\right.$ $\left.S_{n}\right), i=1,2,3$. The payoff matrix is as follows:

\begin{tabular}{|c|c|c|c|c|c|}
\hline players & strategy & $\begin{array}{c}\text { Payoff of } A_{1} \\
H_{1}\left(S_{1} \times S_{2} \times \ldots \times S_{n}\right)\end{array}$ & $\begin{array}{c}\text { Payoff of } A_{2} \\
H_{2}\left(S_{1} \times S_{2} \times \ldots \times S_{n}\right)\end{array}$ & $\ldots \ldots$ & $\begin{array}{c}\text { Payoff of } A_{n} \\
H_{n}\left(S_{1} \times S_{2} \times \ldots \times S_{n}\right)\end{array}$ \\
\hline \begin{tabular}{|l|} 
N bribe \\
\end{tabular} & $(1,1, \ldots, 1)$ & $\left(1 / n-k_{\circ}\right) \Delta V$ & $\left(1 / n-k_{\circ}\right) \Delta V$ & $\ldots \ldots$ & $\left(1 / n-k_{\circ}\right) \Delta V$ \\
\hline$\ldots \ldots$ & & & & & $\ldots \ldots$ \\
\hline 2 bribe & $(1,1, \ldots, 0)$ & $\left(1 / 2-k_{\circ}\right) \Delta V$ & $\left(1 / 2-k_{\circ}\right) \Delta V$ & $\ldots \ldots$. & 0 \\
\hline$\ldots \ldots$ & & & & & $\ldots \ldots$ \\
\hline 2 bribe & $(1,0, \ldots, 1)$ & $\left(1 / 2-k_{\circ}\right) \Delta V$ & 0 & $\ldots . .$. & $\left(1 / 2-k_{0}\right) \Delta V$ \\
\hline$\ldots \ldots$ & $\ldots \ldots$ & $\ldots \ldots$ & $\ldots \ldots$. & $\ldots \ldots$ & $\ldots \ldots$ \\
\hline 2 bribe & $(0,1, \ldots, 1)$ & 0 & $\left(1 / 2-k_{\circ}\right) \Delta V$ & $\ldots \ldots$ & $\left(1 / 2-k_{0}\right) \Delta V$ \\
\hline ....... & & & & & $\ldots \ldots$ \\
\hline 2 bribe & $(0,0, \ldots, 1)$ & 0 & 0 & …. & $\left(1 / 2-k_{\circ}\right) \Delta V$ \\
\hline 1 bribes & $(1,0, \ldots, 0)$ & $\left(1-k_{\circ}\right) \Delta \mathrm{V}$ & 0 & $\ldots \ldots$. & 0 \\
\hline 1 bribes & $(0,1, \ldots, 0)$ & 0 & $\left(1-\mathrm{k}_{\circ}\right) \Delta \mathrm{V}$ & $\ldots \ldots$. & 0 \\
\hline 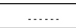 & $\ldots$. & $\ldots \ldots$. & $\ldots \ldots$ & $\ldots \ldots$. & ........ \\
\hline 1 bribes & $(0,0, \ldots, 1)$ & 0 & 0 & $\ldots \ldots$ & $\left(1-\mathrm{k}_{\circ}\right) \Delta \mathrm{V}$ \\
\hline 0 bribes & $(0,0, \ldots, 0)$ & $\Delta \mathrm{V} / \mathrm{n}$ & $\Delta \mathrm{V} / \mathrm{n}$ & $\ldots \ldots$ & $\Delta \mathrm{V} / \mathrm{n}$ \\
\hline
\end{tabular}

According to our analysis, bribery brings payoffs back to the rent seeker, the nash equilibrium of this game is \{bribe, bribe, bribe...bribe $\}$. In equilibrium, no one would deviate from the equilibrium because deviation reduces the payoff. This would certainly lead to the mass breakout of the abuse-of-power crime.

If there are multiple rent seekers in the market, each one of them would choose to bribe the agent to optimize his own profit. Because the payoff of non-bribers is zero, and the market rent would be splitted by the bribing players. according to Xing Ni(1997), on the one hand, the cost paid by rent seekers wouldn't exceed the expected payoff of the rent seeking competition. On the other hand, he has to increase input to succeed in rent seeking. Thus the result of rent seeking competition would converge the cost and expected benefit of rent seeking activity, so that rent seeker would get no extra profit from rent seeking activity compared with other activities, i.e. rent would disappear. (Xing Ni,1997). So bribery is optimal for rent seekers. The 
incentive of bribery turns to maintaining the rent seeker's average profit from maximizing his profit.(Mancang Wang, 1999). When bribery becomes prevalent, rent seekers have to bribe, otherwise his own legal payoff would be retrieved by other players. And the cost of bribery is the price to maintain one's own legal entitlement. The bribery behavior is justified in such circumstance and cannot be denied by laws. According to the Penalty Code in China, if the incentive of bribery is not to attain illegal entitlement, but to maintain one's own legal right, the action of rent seeking cannot be convicted as bribery crime. If the contract is not complete, there would be market failure and government interference comes in, and the resource allocation would partly subject to the government, which produces rent for players to seek.

\subsection{The complete information static game of the agent and the principal}

Because of the rent in the market, if the agent accepts bribery he commits the abuse-of-power crime. For firms, rent seeking activity makes the resource allocation of enterprises inefficient, and reduces the profit of firms and the revenue of principals. For countries, the rent seeking activity would help officials to embezzle the "rent" that belongs to the nation, augmenting the unjust income distribution and thus decreases social welfare. The shareholders and national government, acting as principal, would try to prevent the rent seeking activity. The most fundamental method to do this is to eliminate the rent itself. But it is impossible to do so because of the existence of both the market failure and government, the fundamental measure is to undertake economic and political reform and reduce administrative interference so as to abate the rent to its minimum level. The reform complex carried out by the new cabinet in China is aiming at solving this problem.

In circumstances where the rent cannot be eliminated, a more feasible strategy for the principal to prevent the abuse-of-power crimes is to check the behavior of the agent, and reduce the expected profit of rent seeking by busting the cost through punishment on power abusing.

Suppose that in a market there are one principal and one agent, if the principal do not investigate and prosecute the agent and the agent do not commit crime, the payoff of them are $\mathrm{V}$ and $\mathrm{W}$ respectively. The cost of investigating and prosecution is $\mathrm{C}$, if the agent commits crime the principal would suffer from a loss of $\Delta \mathrm{V}$, but the agent can retrieve benefit of $\mathrm{k}_{0} \Delta \mathrm{V}$. But if this crime is investigated and prosecuted by the principal, the agent has to pay $\mathrm{k}_{1} \Delta \mathrm{V}$ as the price, the rent seeker has to pay $\mathrm{k}_{2} \Delta \mathrm{V}$. The agent's strategy choice is abuse the power or not, the principal's strategy choice is investigate or not. The payoff matrix is as follows:

\begin{tabular}{|l|c|c|c|}
\hline \multicolumn{4}{|c|}{ Tab 4. Game of one principal and one agent } \\
\hline \multicolumn{1}{|c|}{ player } & strategy & $\begin{array}{c}\text { Payoff of } \mathrm{A}_{1} \\
\mathrm{H}_{\mathrm{A}}\left(\mathrm{S}_{1} \times \mathrm{S}_{2}\right)\end{array}$ & $\begin{array}{c}\text { Payoff of } \mathrm{B}_{1} \\
\mathrm{H}_{\mathrm{B}}\left(\mathrm{S}_{1} \times \mathrm{S}_{2}\right)\end{array}$ \\
\hline $\begin{array}{l}\text { Principal investigates } \\
\text { Agent abuses }\end{array}$ & $(1,1)$ & $\begin{array}{c}\mathrm{V}-\mathrm{C}-\Delta \mathrm{V}+\mathrm{k}_{0} \triangle \mathrm{V}+ \\
\mathrm{k}_{1} \Delta \mathrm{V}+\mathrm{k}_{2} \triangle \mathrm{V}\end{array}$ & $-\mathrm{k}_{1} \triangle \mathrm{V}$ \\
\hline $\begin{array}{l}\text { Principal investigates } \\
\text { Agent do not abuse }\end{array}$ & $(1,0)$ & $\mathrm{V}-\mathrm{C}$ & $\mathrm{W}$ \\
\hline $\begin{array}{l}\text { Principal does not investigate } \\
\text { Agent abuses }\end{array}$ & $(\mathrm{O}, 1)$ & $\mathrm{V}-\Delta \mathrm{V}$ & $\mathrm{W}+\mathrm{k}_{0} \triangle \mathrm{V}$ \\
\hline $\begin{array}{l}\text { Principal do not investigate } \\
\text { Agent do not abuse }\end{array}$ & $(\mathrm{O}, 0)$ & $\mathrm{V}$ & $\mathrm{W}$ \\
\hline
\end{tabular}

If the investigation cost $\mathrm{C}$ is big enough, the principal would choose not to investigate. If the punishment afforded by the agent $\mathrm{k}_{2} \Delta \mathrm{V}$ is big enough, the agent would give up committing crime. In case of the principal investigating, the agent would give up committing crime when $\mathrm{W}>\mathrm{W}-$ $\mathrm{k}_{1} \Delta \mathrm{V}$, and commit crime when $\mathrm{W}+\mathrm{k}_{0} \Delta \mathrm{V}>\mathrm{W}$, This reveals that it's necessary for the principal to investigate, and once the investigation and prosecution weakens, more crimes would be committed.

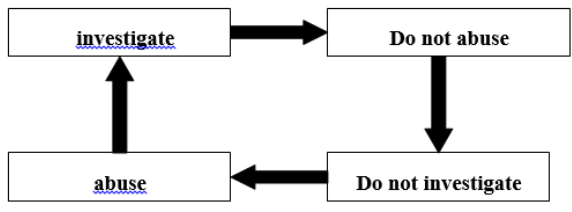

Fig 1. The principal-agent decision circulation

There exists no pure strategy nash equilibrium in this game. So we solve its mixed strategy equilibrium. Suppose the probability of the principal investigating is $\mathrm{p}$ and the probability of the agent abusing is q.

Epected payoff of the principal is

$$
\mathrm{EH}_{\mathrm{A}}=\mathrm{V}+\mathrm{pqC}-\mathrm{pC}-\mathrm{q} \triangle \mathrm{V}+\mathrm{pq} \mathrm{k}_{0} \triangle \mathrm{V}+\mathrm{pq} \mathrm{k}_{1} \triangle \mathrm{V}+\mathrm{pq}
$$
$\mathrm{k}_{2} \triangle \mathrm{V}$

Expected payoff of the agent is

$$
\begin{aligned}
& \mathrm{EH}_{\mathrm{B}}=\mathrm{W}-\mathrm{pqW}+\mathrm{q} \mathrm{k} \mathrm{k}_{0} \triangle \mathrm{V}-\mathrm{pq} \mathrm{k} \mathrm{k}_{1} \triangle \mathrm{V}-\mathrm{pq} \mathrm{k} \mathrm{k}_{0} \triangle \mathrm{V} \\
& \text { F.O.C }
\end{aligned}
$$$$
\frac{\partial E H_{A}}{\partial q}=p C-\Delta V+p k_{0} \Delta V+p k_{1} \Delta V+p k_{2} \Delta V
$$$$
\frac{\partial E H_{A}}{\partial p}=q C-C+q k_{0} \Delta V+q k_{1} \Delta V+q k_{2} \Delta V
$$$$
\text { let } \frac{\partial E H_{A}}{\partial p}=0, \quad \frac{\partial E H_{A}}{\partial q}=0
$$$$
p *=\frac{1}{\frac{C}{\Delta V}+\mathrm{k}_{0}+k_{1}+k_{2}},
$$

$$
q^{*}=\frac{1}{1+\left(k_{0}+k_{1}+k_{2}\right) \frac{\Delta V}{C}}
$$

The size of $\mathrm{p}^{*}$ is determined by various cost $\mathrm{C}$ devoted by the principal to investigate and prosecute, rent $\Delta \mathrm{V}$, the degree of rent seeking $\mathrm{k}_{0}$, the punishment coefficient for the agent $\mathrm{k}_{1}$ and $\mathrm{k}_{2}$

The higher the cost $\mathrm{C}$ is, the smaller the probability of investigation would be. The smaller the rent $\Delta \mathrm{V}$ is, the smaller the probability of investigation would be. The higher the degree of rent seeking $\mathrm{k}_{0}$, the smaller the probability of investigation would be. The bigger the 
punishment coefficient for the agent $\mathrm{k}_{1}$ and $\mathrm{k}_{2}$, the smaller the probability of investigation would be.

The size of $\mathrm{q}^{*}$ is determined by various cost $\mathrm{C}$ devoted by the principal to investigate and prosecute, rent $\Delta \mathrm{V}$, the degree of rent seeking $\mathrm{k}_{0}$, the punishment coefficient for the agent $k_{1}$ and the punishment coefficient for the rent seeker $\mathrm{k}_{2}$.

The higher the cost $\mathrm{C}$ is, the smaller the probability of investigation would be. The smaller the rent $\Delta \mathrm{V}$ is, the bigger the probability of abusing would be. The higher the degree of rent seeking $\mathrm{k}_{0}$, the bigger the probability of abusing would be. The bigger the punishment coefficient for the agent $k_{1}$ and $k_{2}$, the bigger the probability of abusing would be.

\subsection{Analysis of the quantitative function of the abuse- of-power crime}

Based on Becker's analysis, The number of crimes is the function of the expected income of committing the crime $g_{i}$, the probability of getting investigated and prosecuted after committing crimes $p_{i}$, and the severity of punishment $\mathrm{f}_{i}$.

\section{CONCLUSIONS}

The number of crimes is positively correlated with the expected income of committing the crime $g_{i}$, and negatively correlated with the probability of getting investigated and prosecuted after committing crimes $p_{i}$, and the severity of punishment $\mathrm{f}_{i}$.

\section{Acknowledgments}

This paper supported by Science and Research fund project of Chuxiong Normal University (10YJZD02, YJXSDTR06).

\section{Reference}

[1]. Dingding Wang, Economic analysis on corruption, Strategy and Management, 2000(6)

[2]. Fucai Dai, work report of the People's Prosecuting Office of Chuxiong, Chuxiong Daily, Feb $26^{\text {th }}, 2013$

[3]. Gary S. Becker, 1968. "Crime and Punishment: An Economic Approach," Journal of Political Economy, University of Chicago Press, vol. 76, pages 169.

[4]. Gary. S. Becker, The Economic Approach to Human Behavior, The University of Chicago Press, Sept. 1978

[5]. John F. Nash, Lloyd S. Shapley, John C. Harsanyi, Reinhard Selten, Robert J . Aumann, Harold W. Kuhn, Classics in Game Theory Publishing House of Renmin University of China, Jan.2013

[6]. Mancang Wang, Economic analysis on the corruption of public power, Modern Economic Science, Nov. 1999

[7]. "Penal code"of People's Republic of China(revised in 2011), Feb.25,2011

[8]. "Report on the development of rule of law in China No.12(2014)"'Law institute of the Chinese Academy of social sciences, The China's Social Scirnces Literature Press

[9]. Shiyu Xie, Game Theory in Economics, The Fudan University Press, 2007

[10]. Xing $\mathrm{Ni}$, On rent seeking and corruption, Politics Study, 1997(4) 